\title{
ANALISIS PENGARUH LOAN TO DEPOSIT RATIO, DEBT TO EQUITY RATIO DAN RETURN ON INVESTMENT TERHADAP NET INTEREST MARGIN (STUDI KASUS PADA BANK KONVENSIONAL TAHUN 2014-2018)
}

\author{
Budi Junaedi \\ Program Studi Magister Managemen Universitas Tarumanagara \\ budi.junaedi17@gmail.com
}

\begin{abstract}
This study aims to analyze the effect of the loan to deposit ratio variable, debt to equity ratio and return on investment to net interest margins. Research in I took conventional banks listed on the Indonesia Stock Exchange as the subject of research. Data were analyzed statistically through panel data regression analysis with the help of the Eviews program. The results of the analysis show that: (1) Loan to deposit ratio has a significant influence on net interest margin, (2) Debt to equity ratio does not have a significant effect on net interest margin, and (3) Return on investment has a significant effect on net interest margin. Simultaneously, the three independent variables have a significant effect on the net interest margin.
\end{abstract}

Keywords : Loan to Deposit Ratio, Debt To Equity Ratio, Return On Investment, Net Interest Margin

\begin{abstract}
Abstrak : Penelitian ini bertujuan untuk menganalisis pengaruh dari variable loan to deposit ratio, debt to equity ratio dan return on investment terhad ap net interest margin. Penelitian ini mengambil bank konvensional yang terdaftar di Bursa Efek Indonesia sebagai subjek penelitian. Data dianalisis secara statistic melalui analisis regresi data panel dengan bantuan program Eviews. Hasil analisis menunjukkan bahwa: (1) Loan to deposit ratio memberikan pengaruh yang signifikan terhadap net interest margin, (2) Debt to equity ratio tidak memberikan pengaruh yang signifikan terhadap net interest margin, dan (3) Return on investment memberikan pengaruh yang signifikan terhadap net interest margin. Secara simultan ketiga variabel bebas memberikan pengaruh yang signifikan terhadap net interest margin.
\end{abstract}

Kata Kunci : Loan to Deposit Ratio, Debt To Equity Ratio,Return On Investment, Net Interest Margin

\section{LATAR BELAKANG}

Suatu bank dikatakan berhasil memenangkan kompetisi bisnisnya jika ia mampu memberikan jasa layanan keuangan bank lebih baik daripada kompetitornya, sekaligus mampu mengadaptasikan diri dengan setiap perubahan lingkungan. Dengan kemampuan manajerial yang dimiliki, bagaimana para manajer bank dapat mengubah ancaman lingkungan yang turbulen menjadi berbagai peluang usaha yang menguntungkan. Manajemen bank yang kreatifinovatif selalu berusaha menciptakan berbagai produk layanan bank yang prospektif dan menguntungkan tanpa mengabaikanprinsip asset liability managementatau sering disebut langkah menyelaraskan antara profitabilitas dan risiko.

Dalam sebuah usaha, faktor laba bersih (net profit) menjadi elemen yang banyak menyita perhatian. Lembaga keuangan perbankandalam melakukan pengukuran antara pendapatan bunga yang dibayarkan nasabah dan bunga yang dibayarkan kepada pemberi pinjaman salah satunya adalah menggunakan perhitungan Net Interest Margin.Rasio ini dipergunakan untuk mengukur kemampuan manajemen bank dalam mengelola aktiva produktifnya dalam rangka menghasilkan pendapatan bunga bersih. Semakin besar rasio ini maka semakin meningkat pula pendapatan bunga atas aktiva produktif yang dikelola bank, sehingga kemungkinan bank dalam 
kondisi bermasalah semakin kecil. Pada kenyataannya, tidak semua perusahaan pembiayaan memperoleh Net Interest Margin seperti yang diharapkan, karena banyak faktor yang menjadi pertimbangan dalam analisis bisnis.

Salah satu faktor yang memiliki peranan penting dalam menentukan perusabahan net interest margin yaitu besarnya kredit yang disalurkan atas dana yang dimiliki bank atau loan deposit ratio (LDR). Manajemen bank yang konservatif biasanya memiliki kecenderungan loan to deposit ratio yang relatif rendah, sebaliknya manajemen yang agresif memiliki loan to deposit ratio yang tinggi atau melebihi batas toleransi. Semakin tinggi LDR maka akan meningkatkan laba perusahaan, dengan asumsi bank tersebut mampu menyalurkan kredit dengan efektif, sehingga rasio kredit macetnya akan kecil. Pada bank konvensional terjadi penurunan nilai LDR dalam periode 2015 smampai 2017 meskipun pada tahun 2018 mengalami peningkatan. Data loan deposit ratio bank konvensional dalam periode 2015-2018 seperti yang disajikan dalam gambar berikut.

Rasio hutang terhadap modal sendiri atau deb to equity ratio (DER) juga penting untuk mendapat perhatian. Banyaknya hutang perbankan mengindikasikan banyaknya dana masyarakan yang dipercayakan pada pihak perbankan. Ketika dana tersebut dapat disalurkan secara efektif maka akan memberikan profit pada bank, namun ketika dana tersebut tidak dioperasiokan dengan baik maka akan mengganggu kestabilan kegiatan operasional bank, sehingga untuk menjaganya bank harus memiliki modal yang cukup untuk menstabilkan hutang perusahaan. Penelitian yang dilakukan oleh Pinto et al., (2017) membuktikan bahwa debt to equity ratio secara partial memiliki pengaruh yang signifikan terhadap net interest margin.

Sementara itu, dalam menjaga kesetabilan net interest margin juga diperlukan rasio pengembalian investasi, atau sering disebut dengan return on total investment (ROI). Rasio ini melihat sejauh mana investasi yang telah ditanamkan mampu memberikan pengembalian keuntungan sesuai dengan yang diharapkan. Investasi tersebut sebenarnya sama dengan asset perusahaan yang ditanamkan atau ditempatkan. Penelitian yang dilakukan oleh Larley et al. (2013) menyebutkan bahwa ada korelasi positif yang kuat antara margin bunga bersih dan pengembalian aset.

Berdasarkan fenomena yang telah diuraikan maka dimungkinkan bahwa tingkat net interest margin bank konvensional dipengaruhi oleh loan to deposit ratio, debt to equity ratio dan return on investment. Beberapa penelitian menyebutkan bahwa LDR, DER dan ROI/ROA memiliki pengaruh signifikan terhadap NIM (Hastuti, 2011; Pinto et al., 2017; Larley et al. 2013), namun penelitian Syarif (2006) justru menyebutkan bahwa ROA dan LDR tidak memberikan pengaruh signifikan terhadap NIM.

Dengan demikian, penulis tertarik untuk melakukan penelitian lebih lanjut yang diberi judul "Analisis Pengaruh Lon to Deposit Ratio, Debt to Equity Ratio dan Return on Investment terhadap Net Interest Margin (Studi Kasus pada Bank Konvensional tahun 2014-2018)".

\section{PERMASALAHAN}

1. Bagaimana pengaruh Loan to Deposit Ratio (LDR) terhadap Net Interest Margin (Studi Kasus pada Bank Konvensional tahun 2014-2018)?

2. Bagaimana pengaruh Debt to equity ratio (DER) terhadap Net Interest Margin (Studi Kasus pada Bank Konvensional tahun 2014-2018)?

3. Bagaimana pengaruh Return on Investment (ROI) terhadap Net Interest Margin (Studi Kasus pada Bank Konvensional tahun 2014-2018)?

4. Bagaimana pengaruh Loan to Deposit Ratio (LDR), Debt to equity ratio (DER), dan Return on Investment (ROI) secara bersamaan terhadap Net Interest Margin (Studi Kasus pada Bank Konvensional tahun 2014-2018)? 


\section{METODE PENELITIAN}

Variabel yang digunakan dalam penelitian ini dikelompokkan sebagai berikut:

- Variabel terikat (dependent variable)

Variabel terikat dalam penelitian ini adalah Net Interest Margin (NIM) pada Bank Konvensional tahun 2014-2018).

- Variabel bebas (independent variable)

Variabel bebas adalah variabel-variabel yang diduga secara bebas berpengaruh terhadap Net Interest Margin (NIM) Bank Konvensional tahun 2014-2018. Variabel-variabel tersebut adalah :

$\mathrm{X} 1=$ Loan to Deposit Ratio $(L D R)$
$\mathrm{X} 2=$ Debt to equity ratio $(\mathrm{DER})$
$\mathrm{X} 3=$ Return On Investment $(\mathrm{ROI})$

Pada penelitian ini digunakan jenis penelitian dengan teknik purposive sampling terhadap Bank Konvensioal tahun 2014-2018 dan didapatkan 37 perusahaan perbankan yang memenuhi kriteria. Teknik analisa yang digunakan adalah analisa data panel dengan bantuan software Eviews 10, dimana hasil outpur Eviews menujukkan bahwa penggunaan fixed effect model adalah yang terbaik.

\section{HASIL PENELITIAN DAN KESIMPULAN}

Berdasarkan dari hasil analisis data yang telah dilakukan mengenai pengaruh LDR, DER, ROI terhadap Net Interest Margin (NIM) studi kasus pada Bank Konvensional tahun 20142018 maka dapat diambil kesimpulan sebagai berikut :

Hasil penelitian menunjukkan bahwa Loan to Deposit Ratio (LDR) berpengaruh signifikan terhadap Net Interest Margin (NIM) pada Bank Konvensional tahun 2014-2018. Hasil analisis data diperoleh nilai thitung sebesar -11,71211 dengan probabilitas signifikansi yaitu 0,0000 . Terlihat bahwa nilai prob. yang dihasilkan kurang dari $5 \%(0,0000<0,05)$. Sesuai dengan ketentuan dalam pengambilan keputusan jika nilai probabilitas signifikansi (prob. $<0,05$ ), maka Hipotesispertama (H1) diterima, artinya loan to deposit ratio berpengaruh terhadap net interest margin. Adapun arah pengaruh dari hipotesis tersebut yaitu negatif, hal ini sesuai dengan nilai koefisien regresi yang dihasilkan yaitu-0,007844. Setiap terjadi penurunan pada variabel net interest margin diakibatkan oleh peningkatan variabel loan deposit ratio secara signifikan. Hasil penelitian ini sejalan dengan penelitian yang dilakukan oleh Hastuti (2011) yang membuktikan bahwa LDR secara partial berpengaruh signifikan terhad ap NIM.

Varibel Debt to equity ratio (DER) menunjukkan bahwa Debt to Equity Ratio (DER) tidak berpengaruh signifikan terhadap Net Interest Margin (NIM) pada Bank Konvensional tahun 2014-2018. Hasil analisis data diperoleh nilai t hitung sebesar -1.543739 dengan probabilitassignifikansi yaitu 0.1227 . Terlihat bahwa nilai prob. yang dihasilkan lebih besar dari 5\% (0,12227> 0,05). Sesuai dengan ketentuan dalam pengambilan keputusan jika nilai probabilitas signifikansi (sig. $>0,05)$, maka Hipotesisketiga $(\mathrm{H} 2)$ ditolak, artinya debt to equity ratio tidak berpengaruh terhadap net interest margin. Meskipun tidak signifikan, namun arah pengaruh dari hipotesis tersebut yaitu negatif, hal ini sesuai dengan nilai koefisien regresi yang dihasilkan yaitu-0,006502. Peningkatan variabel debt to equity ratio hanya memberikan kontribusi yang sangat kecil pada penurunan net interest margin atau perubahan tidak signifikan.

Variabel Return on Investment (ROI) menunjukkan bahwa Debt to Equity Ratio (DER) berpengaruh signifikan terhadap Net Interest Margin (NIM) pada Bank Konvensional tahun 2014-2018. Hasil analisis data diperoleh nilai thitung sebesar 284,2421 dengan probabilitas signifikansi yaitu 0,0000. Terlihat bahwa nilai prob. yang dihasilkan lebih kecil dari 5\% $(0,0000<0,05)$. Sesuai dengan ketentuan dalam pengambilan keputusan jika nilai probabilitas signifikansi (prob. <0,05), maka Hipotesiskedua (H3) diterima, artinya return on investment 
berpengaruh terhadap Net Interest margin. Adapun arah pengaruh dari hipotesis tersebut yaitu positif, hal ini sesuai dengan nilai koefisien regresi yang dihasilkan yaitu 1,573008. Setiap terjadi penurunan pada variabel net interest margin diakibatkan oleh peningkatan variabel return on investment secara signifikan. Hasil penelitian ini sejalan dengan penelitian yang dilakukan oleh Larley et al. (2013) menyebutkan bahwa ada korelasi positif yang kuat antara margin bunga bersih dan pengembalian aset.

Secara bersama-sama terdapat pengaruh yang signifikan antara loan to deposit ratio, return on investment dan debt to equity ratio terhadap net interest margin. Besarnya kontribusi dari ketiga variabel bebas (loan to deposit ratio, return on investment dan debt to equity ratio) dalam menjelaskan net interest margin ditentukan dari nilai $R$ Square sebesar 88,7568\%.

\section{DAFTAR PUSTAKA}

Alhusin, S. 2003. Aplikasi Statistik Dengan SPSS.10 for Windows. Yogyakarta: Graha Ilmu. Azwar, Saifuddin. 2017. Metode Penelitian Psikologi; Edisi II. Yogyakarta: Pustaka Pelajar. Baltagi, B. H. 2005. Econometric Analysis of Panel Data.England: John Wiley \& Sons Ltd. Fahmi, I. 2014. Analisis Kinerja Keuangan. Bandung: Alfabeta.

Gujarati, D. 2003. Ekonometri Dasar. Terjemahan: SumarnoZain, Jakarta: Erlangga.

Hastuti, P. 2011. Analisis Pengaruh Beban Operasional Pendapatan Operasional (Bopo), NonPerforming Loan (Npl), Capital Adequacy Ratio (Car) Dan Loan To Deposit Ratio (Ldr) Terhadap Net Interest Margin (Nim) (StudiKasus PT Bank Muamalat Indonesia TBK). SkripsiInstitutPertanian Bogor.

Hoang An, P. \& Loan, V. T. K. 2016. Factors affecting net interest margin of joint-stock commercial banks in Vietnam.Journal of Economic Development, V01.24, No.1, h.92103.

Kasmir. 2017. Analisis Laporan Keuangan. Jakarta: Raja GrafindoPersada.

Larley, V. C., Antwi, S. \&Boadi, E. K. 2013.The Relationship between Net Interest Margin and Return onAssets of Listed Banks in Ghana.Research Journal of Finance and Accounting, Vol.4, No.16, h.73-78.

Kerlinger. F. N. 2004. Asas-asas Penelitian Behavioral. Yogyakarta: Universitas Gadjah mada. Otoritas Jasa Keuangan. 2018. Statistik Perbankan Indonesia. Jakarta: OJK.

Pinto, P., Hawaldar, I. T., Maria, J. \& Joseph, N. R. 2017.Capital Structure and Financial Performance of Banks. International Journal of Applied Business and Economic Research, Vol.15, No.23, h.303-312.

Rivai, V., Veithzal, A. P. \&Idroes, F. N. 2007.Bank and Financial Institute Management. Jakarta: PT. Raja GrafindoPersada.

Santoso, S. 2014. SPSS 22 from Essential to Expert Skills.Jakarta: Gramediaanggota IKAPI.

Sarwono, J. 2006. Metode Penelitian Kuantitatif dan Kualitatif. Yogyakarta: Graha Ilmu.

Sekaran, U \& Bougir, R. 2013.Research Methods for Business: A skill Building Approach. New York: John Willey and Sons.

Sipahutar, M. A. 2007. Persoalan-Persoalan Perbankan Indonesia. Jakarta Pusat: Georga Media.

Syarif, S. 2006. Analisis Pengaruh Rasio-Rasio Camels Terhadap Net Interest Margin (Study Empiris Pada Bank-bank yang Listed di Bursa Efek JakartaPeriodeTahun 2001 - 2004). Tesis Universitas Diponegoro.

Sugiyono. 2017. Metode Penelitian Kuantitatif, kualitatif dan R\&D. Bandung: Alfabeta 